\title{
Genetic monitoring of a Santa Ines herd using microsatellite markers near or linked to the sheep $\mathrm{MHC}^{1}$
}

\author{
César Daniel Petroli ${ }^{2}$, Samuel Rezende Paiva ${ }^{3}$, Marilma Pachêco Chediak Corrêa ${ }^{4}$, Concepta \\ McManus $^{2}$
}

\author{
${ }^{1}$ CNPq, UnB, EMBRAPA, FAPDF. \\ 2 Faculdade de Agronomia e Medicina Veterinária, Universidade de Brasília, Brasília, DF. \\ ${ }^{3}$ Laboratório Genética Animal, Embrapa Recursos Genéticos e Biotecnologia, Brasília, DF. \\ ${ }^{4}$ Universidade Católica de Goiás e Universidade Federal de Goiás, Pós-graduação em Ciência Animal, Goiânia, GO.
}

\begin{abstract}
This study aimed to analyze genetic diversity in a conservation nucleus of Santa Inês sheep using thirteen microsatellite loci on chromosome 20 (where the Sheep Major Histocompatibility Complex - Ovar-MHC - is found). Seventy three animals from one herd born from 2004 to 2006 were evaluated as a principal nucleus. Seventy one animals from two other herds were used as control comparison. There was a reduction in heterozygosity over the years in relation to the whole population. This may be due to the repeated use of the same sires. The estimates of molecular coancestrality also indicated an increase in genetic similarity between individuals with the herd over the years. A high number of alleles occurred exclusively in the principal nucleus herd, but with a frequency lower than $10 \%$. The Ovar-MHC region of chromosome 20 was shown to be highly polymorphic. Monitoring of the herd over time should be implemented as additional tool for genetic management within the herd.
\end{abstract}

Key Words: animal genetic resources, genetic diversity, Ovar-MHC, Ovis aries, molecular coancestrality, SSR

\section{Monitoramento genético de um rebanho da raça Santa Inês a partir de marcadores microssatélites próximos ou ligados ao MHC ovino}

RESUMO - O objetivo neste trabalho foi analisar a diversidade genética de um núcleo de conservação da raça Santa Inês utilizando-se 13 locos de microssatélites localizados no cromossomo 20, onde se encontra o Complexo Maior de Histocompatibilidade ovino - Ovar-MHC. Foi avaliado um total de 73 animais nascidos nos anos de 2004, 2005 e 2006 mais 71 animais de outros dois rebanhos como controles. Em geral, constatou-se redução na heterozigosidade dos indivíduos ao longo dos anos em relação à população total, talvez pela baixa rotatividade de reprodutores. As estimativas de co-ancestralidade molecular também evidenciaram aumento da similaridade genética entre os indivíduos do rebanho ao longo dos anos. Há elevado número elevado de alelos privados na população principal, embora esses alelos tenham freqüência menor que $10 \%$. A região do Ovar-MHC do cromossomo 20 ovino foi altamente polimórfica e pode ser usada para auxiliar na manutenção de rebanhos. A continuação deste monitoramento ao longo dos anos é desejável e deve ser implantada como ferramenta adicional visando, por exemplo, indicação de acasalamentos e descarte de animais.

Palavras-chave: coancestralidade molecular, diversidade genética, Ovar-MHC, Ovis aries, recursos genéticos animais, SSR

\section{Introduction}

Selection is one of the main tools used in an animal breeding program which identifies animals which should be used to produce the next generation. If this is not carried out with carefully selected criteria, it may, among other things, increase inbreeding within a population. Other factors associated with selection which may affect inbreeding include a structure of populations within and between herds and management directed towards the use of just a few sires (Goyache et al., 2003). This practice reduces the effective size of the population and therefore genetic variability (Kantanen et al., 1999). Additionally, the selection of animals in a random manner may cause fixation of unfavorable alleles in the population (Crisà et al., 2001).

The Major Histocompatibility Complex (MHC) in vertebrates involves a series of highly polymorphic genes which are responsible for the initiation of the immune response of the organism when challenged by pathogens or parasites (Gaudieri et al., 2000; Gruszczynska et al., 2002; Diaz et al., 2005; Geldermann et al., 2006; Schaschl 
et al., 2006; Santucci et al., 2007). Another important trait of this region of the genome is that its structure is relatively conserved between different ruminant species (Ballingall \& McKeever, 2005).

According to Klein (1976), the MHC is divided in three regions, class 1 (telomeric), class 2 (centromeric), and class 3 (central). In ruminants there is a division of the Class 2 region in two sub-regions, Class 2a and Class 2b (Andersson et al., 1988). Various studies have shown the existence of polymorphisms in each of these regions (Campbell et al., 1986; Buitkamp et al., 1996; Paterson et al., 1998; Gruszczynska, 1999; Gruszczynska et al., 2000; Kulski et al., 2002). In sheep, the OLA (Ovine Leukocyte Antigen System) is localized on chromosome 20 (Scott et al., 1992; De Gotari et al., 1998).

The high variability of the MHC, together with the qualities of microsatellite markers (Powel et al., 1996; Ferreira \& Grattapaglia, 1998; Guimarães, 2001), may be an excellent alternative for aiding/monitoring genetic management in herds. In this study the genetic variability of microsatellite loci localized within or close to the MHC region in Santa Inês sheep was studied and their viability tested in analyses of herd management in the Center-West region of Brazil.

\section{Material and Methods}

Blood samples from 144 Santa Inês sheep were collected by venal puncture between 2004 and 2006 using $5 \mathrm{~mL}$ vacutainers with an anticoagulant (EDTA) and kept refrigerated $\left(4-8^{\circ} \mathrm{C}\right)$ until processing for separation of lymphocytes. The animals were from three different farms:

1) 73 from the University of Brasilia (UnB) farm;

2) 54 from a herd closed for at least 6 years from the Catholic University of Goias (UCG); and

3) 17 from a private herd in the Federal District (DF), Brazil, where there is a constant change of dams and sires from farms different from those above. To evaluate temporal genetic variability of the animals from UnB blood was collected on three different occasions ( $\mathrm{N}=22$ in 2004, $\mathrm{N}=32$ in 2005 and $\mathrm{N}=19$ in 2006) and full sibs were excluded (including those collected within the same year). The climate in the region is AW classified by Köppen. Genomic DNA was extracted using the protocol described by Miller et al. (1988). The DNA was then diluted (3ng/ $\mu \mathrm{L}$ ), quantified by spectrophotometry and agarose gel $1 \%$ and stored until use.
Thirteen microsatellite loci were selected to study the genetic variability within the sheep MHC. These were localized within or in regions adjacent to the sheep MHC (Table 1). Amplification of the microsatellites was carried out using the PCR technique (Polymerase Chain Reaction). $1.5 \mu \mathrm{L}$ of each sample of DNA [3ng/ $\mu \mathrm{L}$ ] were used; $1.0 \mu \mathrm{L}$ Tris-HCl 10\%(pH8,4); $0.2 \mu \mathrm{L}-0.5 \mu \mathrm{L} \mathrm{MgCl}_{2}[1.0 \mu \mathrm{M}-2.5 \mu \mathrm{M}]$; $0.8 \mu \mathrm{L} d N T P[2.5 \mu \mathrm{M}] ; 1.0 \mu \mathrm{L}$ BSA [1.0 mg/mL]; 0.1 $\mu \mathrm{L}$ Taq DNA polymerase $(\mathrm{pHT})[5 \mathrm{Ud} / \mu \mathrm{L}] ; 0.3 \mu \mathrm{L}$ Primer $(\mathrm{F}+\mathrm{R})$ [10 $\mu \mathrm{M}$ ]; and water to complete $10 \mu \mathrm{L}$ final volume. The PCR program included an initial desnaturation step at $94^{\circ} \mathrm{C}$ for 5 minutes; 35 cycles of desnaturation at $94^{\circ} \mathrm{C}$ for 1 minute, annealing with temperatures varying between $49^{\circ} \mathrm{C}$ and $65^{\circ} \mathrm{C}$ for 45 seconds (depending on the primer used), and $72^{\circ} \mathrm{C}$ for 1 minute for extension. At the end of the 35 cycles a final extension at $72^{\circ} \mathrm{C}$ for 30 minutes was used to reduce the number of spurious fragments (stutter bands).

The PCR amplification success was initially observed in $2 \%$ agarose gels coloured with ethidium bromide. Standardized samples with molecular weight of $1 \mathrm{~kb}$ (Invitrogen) were applied to the gels for comparison of the fragment size obtained. After visualization in agarose, the samples underwent multiplex capillary electrophoresis in an Automatic Sequencer model ABI 3100 or 3700 (Applied Biosystems) to optimize the electrophoresis. The analysis of the electrophoresis and allele genotyping was carried out using the softwares GeneScan and Genotyper (Applied Biosystems). All molecular analyses were carried out in EMBRAPA Genetic Resources and Biotechnology - Cenargen.

Various herd genetic population characteristics were calculated using the softwares Arlequin v.3.1 (Excoffier et al., 2005), Genepop (Raymond \& Rousset, 1995), Genalex (Peakall \& Smouse, 2005), FSTAT (Goudet 2002) and Molkin (Gutiérrez et al., 2005). These parameters included: mean number of alleles $\left(A_{M}\right)$, allelic richness $\left(A_{R}\right)$, private allelic richness $\left(A_{P}\right)$, as well as observed heterozygosity (Ho), expected heterozygosity (He), Hardy - Weinberg Equilibrium test (EHW) and linkage disequilibrium between each pair of loci in each population studied. Desequilibrium was estimated using permutations carried out between pairs of loci in all herds, and the calculations undergoing the Bonferroni correction in the Genepop program Version 3.1d (Raymond \& Rousset, 1995). Fixation indices (or the inbreeding coefficient) within each population $\left(\mathrm{F}_{\mathrm{IS}}\right)$ were also calculated, as well as mean molecular coancestrality in the different populations. 
Table 1 - Microsatellite markers and their selected primers on chromosome 20 of Ovis aries with their estimated position on the genetic map

\begin{tabular}{|c|c|c|c|c|}
\hline Locus & Synonomyn & $\begin{array}{l}\text { Position } \\
(\text { v. }, 4.7)^{1}\end{array}$ & $\begin{array}{c}\text { Primer sequence } \\
\text { 5' - 3' }\end{array}$ & Reference \\
\hline INRA132 & INRA 104 & 9.5 & $\begin{array}{l}\mathrm{F}: \text { aacatttcagctgatggtggc } \\
\mathrm{R}: \text { ttctgttttgagtggtaagctg }\end{array}$ & de Gortari et al. (1998) \\
\hline DYA & DYMS1 & 11.6 & $\begin{array}{l}\text { F: aacaccatcaaacagtaagag } \\
\text { R: catagtaacagatcttcctaca }\end{array}$ & Buitkamp et al. (1996) \\
\hline OarCP101 & СР101 & 31.2 & $\begin{array}{l}\text { F: tcataccttaagagagtcgag } \\
\text { R:ctatcagacagacagtcagacagtcag }\end{array}$ & Crawford et al. (1995) \\
\hline DQBA27 & DQB & 41.3 & $\begin{array}{l}\text { F: tccccgcagaggatttcgtg } \\
\text { R: tccgccgctgccaggtgaag }\end{array}$ & Maddox, J.F. Unpublished. \\
\hline OLADRB & DRB2 & 46.3 & $\begin{array}{l}\text { F: ctgccaatgcagagacacaaga } \\
\text { R: gtctgtctcetgtcttgtcatc }\end{array}$ & Schwaiger et al. (1993) \\
\hline DQA1 & OLA-DQA1 & 55.5 & $\begin{array}{l}\text { F: accetgactcagctgacc } \\
\text { R: catactgttggtagcagc }\end{array}$ & Snibson et al. (1998) \\
\hline Bf94_1 & Bfms & 57.7 & $\begin{array}{l}\text { F: caacggtctgcaaccgaattacc } \\
\text { R: caatccgtgggttggaacacaa }\end{array}$ & Groth et al. (1995) \\
\hline BM1818 & - & 58.9 & $\begin{array}{l}\text { F: agctgggaatataaccaaagg } \\
\text { R: agtgctttcaaggtccatgc }\end{array}$ & Bishop (1994) \\
\hline OMHC1 & SMHCC1 & 59.6 & $\begin{array}{l}\text { F: atctggtgggctacagtccatg } \\
\text { R: gcaatgctttctaaattctgaggaa }\end{array}$ & Groth \& Wetherall (1994) \\
\hline TFAP2A & - & 71.4 & $\begin{array}{l}\text { F: ctattaggaggctccaggaacgct } \\
\text { R: ctggtcgaacccacggtctctat }\end{array}$ & Maddox J.F. Unpublished. \\
\hline
\end{tabular}

${ }^{1}$ Position in centiMorgans on chromosome 20 (http://rubens.its.unimelb.edu.au/ jillm/jill.htm).

\section{Results and Discussion}

Analyses of loci DQA2 and TFAP2A were not included in the final results as they did not amplify adequately. Therefore, 11 loci were amplified and analysed. The population of the Catholic University in Goiania had the greatest number of loci out of equilibrium (nine of eleven) while the population from the private farm in the DF (DFC) had only four of the eleven loci outside the expected proportions (Table 2). The BM1818, OarHH56, DQBA27, OarCP101 and DQA1 loci showed deviation from EHW in four of the five populations. Only locus INRA132 did not show significant deviations from EHW. Santucci et al. (2007), studying European sheep breeds with microsatellite markers localized on the MHC and in other regions of the genome, also found significant deviations from EHW. These authors justified that present management practices such as the use of few sires and exchange of sires with neighbouring herds leads to an increase in the complexity for interpretation of genetic structure of populations using traditional measures of population genetics.

These results (significant deviations from expected EHW) are expected as they were studyed in closed herds or herds with small effective population size with low gene flow (ex., UCG), or with directed crossings (UnB and DFC). An alternative explication for this pattern may be due to the stabilizing effect which occurs in this region of the genome (Garrigan \& Hedrick, 2003). In this way, some alleles of microsatellite loci may be linked to the genes of the MHC.

Similar to the results for EHW, the population from UCG showed the greatest number of pairs of loci $(\mathrm{P}<0.05$ with Bonferroni correction) significantly in linkage disequilibrium, five of the possible 55 combinations or approximately $10 \%$. The other populations, with the exception of the 2006 population from UnB, showed only a single combination in disequilibrium (1.8\%). In $75 \%$ of the linkage disequilibrium loci combinations the locus OarHH56 was present, which is 
Table 2 - Observed (Ho) and expected (He) heterozygosity of eleven loci located on chromosome 20 in five populations of Santa Inês and test for Hardy -Weinberg equilibrium

\begin{tabular}{|c|c|c|c|c|c|c|c|c|c|c|}
\hline Locus & \multicolumn{2}{|c|}{$\mathrm{DFC}^{1}$} & \multicolumn{2}{|c|}{$\mathrm{UCG}^{1}$} & \multicolumn{2}{|c|}{ UnB $2004^{1}$} & \multicolumn{2}{|c|}{ UnB $2005^{1}$} & \multicolumn{2}{|c|}{ UnB $2006^{1}$} \\
\hline DYA & 0,65 & 0,70 & 0,58 & $0,79 *$ & 0,50 & $0,86^{*}$ & 0,60 & $0,86 *$ & 0,63 & 0,88 \\
\hline OarHH56 & 0,47 & $0,80 *$ & 0,64 & $0,72 *$ & 0,55 & 0,73 & 0,43 & $0,67 *$ & 0,53 & $0,74 *$ \\
\hline DQBA27 & 0 & $0,47^{*}$ & 0 & $0,60^{*}$ & 0 & $0,44^{*}$ & 0,12 & $0,60 *$ & 0,20 & 0,19 \\
\hline INRA132 & 0,38 & 0,34 & 0,47 & 0,52 & 0,19 & 0,36 & 0,45 & 0,55 & 0,53 & 0,56 \\
\hline DQA1 & 0,13 & $0,46 *$ & 0,02 & $0,15^{*}$ & 0,09 & $0,35 *$ & 0 & $0,12 *$ & 0 & 0,11 \\
\hline OarCP73 & 0,38 & 0,52 & 0,08 & $0,50 *$ & 0,13 & 0,23 & 0,21 & $0,57 *$ & 0,06 & $0,48 *$ \\
\hline OLADRB & 0,73 & 0,83 & 0,64 & $0,79 *$ & 0,71 & 0,84 & 0,41 & $0,83^{*}$ & 0,78 & 0,75 \\
\hline Bf94_1 & 0,69 & 0,67 & 0,08 & 0,12 & 0,59 & 0,628 & 0,19 & $0,50 *$ & 0,26 & $0,37 *$ \\
\hline Mean & 0,42 & 0,61 & 0,33 & 0,56 & 0,36 & 0,62 & 0,31 & 0,61 & 0,33 & $0,53 *$ \\
\hline
\end{tabular}

${ }^{1}$ DFC: private farm in the Distrito Federal; UCG: Universidade Católica de Goiás; UnB: Universidade de Brasília; *significant loci at p<0.01 for deviation from HardyWeinberg Equilibrium.

found close to one of the extremities of chromosome 20 of Ovis aries. Gametic disequilibrium is the non-random association of different alleles from different loci in the gametes. Linkage disequilibrium may happen due to various genetic factors, from physical linkage (on the same chromossome), due to different selection processes (for example, epistatic selection and genetic lift) or by genetic drift in finite populations. In addition, it may occur due to demographic factors such as co-ancestry, migration and inter-crossing of populations. In the case in question, where the markers are on the same chromosome, physical linkage cannot be discarded. Another process which may influence the results is genetic drift as the population from UCG has a small effective size with probably high rate of inbreeding.

Gametic disequilibrium may also be influenced by the existence of a structure within or between the populations studied. An analysis of molecular variance (AMOVA) was carried out to test the hypothesis of differentiation between the populations. This found that $8.01 \%(\mathrm{P}<0.01)$ of all observed variation was due to differences between the populations Santa Inês studied. This is a relatively high value for populations within a breed. Paiva (2005) found $11.76 \%$ differentiation between 10 sheep breeds in Brazil using 19 microsatellite loci spread over the genome. With this, it is expected that the structure of populations, at least within the Santa Ines breed, influences linkage disequilibrium. Confirmation of this hypothesis would only be possible with a new study with more samples, the least degree of relationship between animals and more markers.

In relation to the observed heterozygosity values it can be seen that the population in UnB from 2005 had the lowest mean value (0.31) and the population from the private farm had the highest observed value (0.42) (Table 2). These values are well below those observed by Paiva (2005), but as they are related to markers on a single chromosome and many of these are probably under selection these values are within expected values. Comparisons with other studies were not carried out as markers used were different.

The analysis of other estimated population parameters (Table 3) showed some patterns which are in agreement with the heterozygosity results. The $\mathrm{F}_{\mathrm{IS}}$ values show higher inbreeding in the DFC population. On the other hand, the parameters related with variability of alleles are not directly related with heterozygosity, but with molecular coancestry. This is an important result, as it shows that decision making and conclusions based on heterozygosity values are risky and may mask the present genetic state of the population. The population from UnB shows higher mean variability of alleles when compared with the DFC population. The heterozygosity may be influenced by the entrance of new alleles in a population and this is relatively common in commercial properties where sires are exchanged at least once a year.

The final pattern identified was the decrease in genetic variability over the three years in the UnB herd. Practically all the parameters showed the same tendency, but molecular coancestry and presence of private alleles were clearer in showing this tendency (Table 3). Individual mean molecular coancestry values varied from 0.16 (UnB 2005) to 0.64 (UCG) and suggest that it would be impossible to install a program of genetic management to optimize variability of the herds using the reduction in mean individual coancestry. This decrease in genetic diversity and increase in endogamy within the UnB herd can be explained by use of few sires as well as their use with different numbers of females in recent years. In this way, the last year studied may have animals that are more related. Another common practice which may explain this pattern is the permanence of females within the herd born in previous years. 
Table 3 - Genetic diversity in Five Santa Ines sheep populations for eleven microsatellite markers on chromosome 20 of Ovis aries. $\mathrm{N}=$ number of animals sampled per population, $\mathrm{A}_{\mathrm{M}}=$ mean number of alleles, $\mathrm{A}_{\mathrm{R}}=$ allelic richness; $\mathrm{f}_{\mathrm{M}}=$ mean molecular coancestry; $\mathrm{F}_{\mathrm{IS}}=$ inbreeding coefficient within each population; $\mathrm{A}_{\mathrm{P}}<10 \%=$ number of specific alleles with frequency lower than $10 \% ; A_{P}>10 \%=$ number of specific alleles with frequency higher than $10 \%$

\begin{tabular}{|c|c|c|c|c|c|c|c|}
\hline \multirow[t]{2}{*}{ Population $^{1}$} & \multicolumn{7}{|c|}{ Indices } \\
\hline & $\mathrm{N}$ & $\mathrm{A}_{\mathrm{M}}$ & $A_{R}$ & $f_{M}$ & $\mathrm{~F}_{\text {IS }}$ & $A_{P}<10 \%$ & $A_{P}>10 \%$ \\
\hline DFC & 17 & 4,45 & 4,04 & 0,38 & 0,27 & 0 & 0 \\
\hline UCG & 54 & 5,27 & 3,93 & 0,47 & 0,36 & 0 & 0 \\
\hline UnB 2004 & 22 & 5,64 & 4,82 & 0,36 & 0,37 & 2 & 2 \\
\hline UnB 2005 & 32 & 5,64 & 4,55 & 0,42 & 0,46 & 3 & 0 \\
\hline UnB 2006 & 19 & 5,18 & 4,21 & 0,46 & 0,38 & 0 & 0 \\
\hline Média & - & 5,24 & 4,981 & 0,43 & 0,38 & - & - \\
\hline
\end{tabular}

${ }^{1}$ DFC, private farm DF; UCG, Universidade Católica de Goiás; and UnB, Universidade de Brasília.

The use of molecular coancestry as indices for monitoring genetic diversity has shown promising and robust results (Royo et al., 2007; Toro et al., 2003; Toro et al., 2002). The results presented here are additional evidence of the use of this parameter as an accessory tool, together with pedigree data for management of animal genetic resources, as well as show that loci close to the MHC may be used as markers of genetic variability. Markers can be used as an aid to selection decision in carrying out directed mating, culling, as well as parentage confirmation. It is important to note that the use of genetic markers for the specific function of maintaining genetic variability would only de desirable, or would have greater response, in herds that never underwent genetic management or that had problems with the collection of production data in some generations. Genetic management using traditional methods based on pedigree are still very efficient for the maintenance of genetic variability within herds (Fernández et al., 2005). As the herd from UnB is experimental in nature, the tendency is to continue to accompany this population for some more years using molecular markers to evaluate their potential and, together with pedigree data, steer matings to increase genetic variability through reduction of coancestry within the herd.

\section{Conclusion}

The results show the analytic capacity of this panel of microsatellite markers in capturing genetic variability of the Santa Inês breed. This study also shows how markers can be used to aid in genetic management of sheep herds in Brazil. For breeding programs this panel as well as others may be used to verify the accuracy of pedigrees. The application of these markers would have a greater impact on herds without much production control or those that have problems with pedigree recording.

\section{Literature Cited}

ANDERSSON, L.; LUNDÉN, A.; SIGURDARDÓTTIR, S. et al. Linkage relationships in the bovine MHC region, High recombination frequency between class II subregions. Immunogenetics, v.27, n.4, p.273-280, 1988.

BALLINGALL, K.T.; MCKEEVER, D.J. Conservation of promoter, coding and intronic regions of the non-classical MHC class II DYA gene suggests evolution under functional constraints. Animal Genetics, v.36, n.3, p.237-239, 2005.

BISHOP, M.D.; KAPPES, S.M.; KEELE, J.W. et al. A genetic linkage map for cattle. Genetics, v.136, p.619-639, 1994.

BUITKAMP, J.; FILMETHER, P.; STEAR, M.J. et al. Class I and class II major histocompatibility complex alleles are associated witn faecal egg counts following natural, predominantly Ostertagia corcumcincta infection. Parasitology Research, v.82, n.8, p.693-696, 1996.

CAMPBELL, R.D.; CARROLL, M.C.; PORTER, R.R. The molecular genetics of component of complement. Advanced Immunology, v.38, p.203-244, 1986.

CRAWFORD, A.M.; DODDS, K.G.; EDE, A.J. et al. An autosomal genetic linkage map of the sheep genome. Genetics v.140, p.703-724, 1995.

CRISÀ, A.; PARISET, L.; MARCHITELLI, L. et al. Analisi della distribuzione dell'allele D della caseina alfa S1 in un campione di allevamenti nell'alto Lazio mediante ACRS. In: CONVEGNO NAZIONALE SULLA BIODIVERSITÀ "OPPORTUNITÀ DI SVILUPPO SOSTENIBILE”, 6., 2001, Bari, Italy. Proceedings... Bari: 2001. (CD-ROM).

DE GOTARI, M.J.; FREKING, B.A.; CUTHBERTSON, R.P. et al. A second generation linkage map of the sheep genome. Mammalian Genome, v.9, p.204-209, 1998.

DÍAZ, S.; RIPOLI, M.V.; PERAL-GARCÍA, P. et al. Marcadores genéticos para resistencia y susceptibilidad a enfermedades infecciosas en animales domésticos. Los loci del complejo principal de histocompatibilidad (mhc) como genes candidatos. Analecta Veterinaria, v.25, n.1, p.40-52, 2005.

EDE, A.J.; PIERSON C.A.; CRAWFORD, A.M. Ovine microsatellites at the OarCP34, 0arCP38, 0arCP43, OarCP49, 0arCP73 and OarCP79 loci. Animal Genetics, v.26, p.130-131, 1995.

EDE, A.J.; PEIRSON, C.A.; HENRYA, H. et al. Ovine microsatellites at the OarAE64, OarHH22, OarHH56, OarHH62 and OarVH4. Animal Genetics, v.25, p.51-52, 1994.

EXCOFFIER, L.; LAVAL, G.; SCHNEIDER, S. Arlequin ver. 3.0: An integrated software package for population genetics data analysis. Evolutionary Bioinformatics Online, v.1, p.47-50, 2005.

FERNÁNDEZ, J.; VILLANUEVA, B.; PONG-WONG, R. et al. Efficiency of the use of pedigree and molecular marker 
information in conservation programs. Genetics, v.170, p.1313-1321, 2005

FERREIRA, M.E.; GATTAPAGLIA, D. Introducción al uso de marcadores moleculares en el análisis genético. 1.ed. Brasilia: Embrapa Cenargen, 1998. 220p.

GARRIGAN, D.; HEDRICK, P.W. Perspective: detecting adaptive molecular polymorphims: lessons from the MHC. Evolution, v.57, p.1707-1722, 2003.

GAUDIERI, S.; DAWKINS, R.L.; HABARA, K. et al. SNP profile within the human major histocompatibility complex reveals an extreme and interrupted level of nucleotide diversity. Genome Research, v.10, p.1579-1586, 2000.

GELDERMANN, H.; MIR, M.R.; KUSS, A.W. et al. OLADRB1microssatellite variants are associated with ovine growth and reproduction traits. Genetic Selection and Evolution, v.38, p.431-444, 2006.

GOUDET J. FSTAT Version 2.9.3.2 for windows: a computer program to calculate F-statistics. 2002. Disponível em: <http://www2.unil.ch/popgen/softwares/fstat.htm>. Acesso em: 21/12/2003.

GOYACHE, F.; GUTIÉRREZ, J.P.; FERNANDEZ, I. et al. Using pedigree information to monitor genetic variability of endangered populations: the Xalda sheep breed of Asturias as an example. Journal of Animal Breeding and Genetics, v.120, p.95-105, 2003.

GROTH, D.M.; WETHERALL, J.D. Dinucleotide repeat polymorphism adjacent to sheep complement factor B. Animal Genetics, v.26, p.282-283, 1995.

GROTH, D.M.; WETHERALL, J.D. Dinucleotide repeat polymorphism within the ovine major histocompatibility complex class I region. Animal Genetics, v.25, p.61, 1994.

GRUSZCZYNSKA, J. Polymorphism of the OLADRB1 (MHC Class II) gene in German Merino sheep. Annals of Warsaw Agricultural University - SGSW, Animal Science, v.35, p.125-132, 1999.

GRUSZCZYNSKA, J.; CHARON, K.; SZDLOWSKI, M. Effect of foeto - maternal immunization in sheep on birth weight and live weight gain of lambs. Animal Science Papers and Reports, v.18, p.65-76, 2000.

GRUSZCZYNSKA, J.; CHARON, K.M.; SWIDEREK, W. et al. Microsatellite polymorphism in locus OMHC1 (MHC Class I) in Polish Heath sheep and Polish Lowland sheep (Zelazna variety). Journal of Applied Genetics, v.43, n.2, p.217-222, 2002.

GUIMARÃES, S.E.F. Análise de marcadores genômicos e detecção de QTL's e genes candidatos em melhoramento animal. In: PEREIRA, J.C.C. (Ed.) Melhoramento genético aplicado à produção animal. 2.ed. Belo Horizonte: Fundação de Estudo e Pesquisa em Medicina Veterinária e Zootecnia, 2001. p.383-418.

GUTIÉRREZ, J.P.; ROYO, L.J.; ÁLVAREZ, I. et al. MolKin v. 2,0: a computer program for genetic analysis of populations using molecular coancestry information. Journal of Heredity, v.96, n.6, p.718-72, 2005

KANTANEN, J.; OLSAKER, I.; ADALSTEINSSON, S. et al. Temporal changes in genetic variation of North European cattle breeds. Animal Genetics, v.30, p.6-28, 1999.
KLEIN, J. Evolution and function of the major histocompatibility complex: facts and speculations, In: GOTZE, D. (Ed.) The major histocompatibility system in man and animals. Springer-Verlag New York, 1976. p.339-378.

KULSKI, J.K.; SHIINA, T.; ANZAI, T. et al. Comparative genome analysis of the MHC: the evolution of class I duplication blocks, diversity and complexity from shark to man. Immunology Review, v.190, p.95-122, 2002.

MILLER, S.A.; DYKES, D.D.; POLESKY, H.F. A simple satting out procedure for extracting DNA from human nucleated cells. Nucleic Acids Research, v.16, p.1215, 1998.

PAIVA, S. Caracterização da diversidade genética de ovinos no Brasil com quatro técnicas moleculares. 2005. 118f. Tese (Doutorado em Genética e Melhoramento) - Universidade Federal de Viçosa, Viçosa, MG, 2005.

PATERSON, S.; WILSON, K.; PEMBERTON, J.M. Major histocompatibility complex variation associated with juvenile survival and parasite resistance in a large unmanaged ungulate population (Ovis aries L.). Proceedings of the National Academy of Science, v.95, p.3714-3719, 1998.

PEAKALL, R.; SMOUSE, P.E. GENALEX 6: genetic analysis in Excel. Population genetic software for teaching and research. Australian National University: 2005. (CD-ROM).

POWEL, W.; MORGANTE, M.; ANDRE, C. et al. The comparison of RFLP, RAPD, AFLP and SSR (Microsatellite) markers for germplasm analysis. Molecular Breeding, v.2, p.225-238, 1996.

RAYMOND, M.; ROUSSED, M. GENEPOP: an exact test for population differentiation. Evolutionary Biology, v.49, n.6, p.1280-1283, 1995.

ROYO, L.J.; ÁlVAREZ, I.; GUTIÉRREZ, J.P. et al. Genetic variability in the endangered Asturcón pony assessed using genealogical and molecular information. Livestock Science, v.107, p.162-169, 2007.

SANTUCCI, F.; IBRAHIM K.M.; BRUZZONE, A. et al. Selection on MHC-linked microsatellite loci in shepp populations. Heredity, v.99, n.3, p.340-348, 2007.

SCHASCHL, H.; WANDELER, P.; SUCHENTRUNK, F. et al. Selection and recombination drive the evolution of MHC class II DRB diversity in ungulates. Heredity, v.97, n.6, p.427-437, 2006.

SCHWAIGER, F.W.; BUITKAMP, J.; WEYERS, E. et al. Typing of artiodactyl MHC-DRB genes with the help of intronic simple repeated DNA sequences. Molecular Ecology, v.2, p.55-59, 1993.

SCOTT, P.C.; MADDOX, J.F.; GOGOLIN-EWENS, K.J. et al. The nucleotide sequence and evolution of ovine MHC class II B genes: DQB and DRB. Immunogenetics, v.34, p.80-87, 1992.

SNIBSON, K.J.; MADDOX, J.F.; FABB, S.A. et al. Allelic variation of ovine MHC class II DQA1 and DQA2 genes. Animal Genetics, v.29, n.5, p.356-362, 1998.

TORO, M.A.; BARRAGÁN, C.; ÓVILO, C. Estimation of genetic variability of the founder population in a conservation scheme using microsatellites. Animal Genetics, v.34, p.226-228, 2003.

TORO, M.A.; BARRAGÁN, C.; ÓVILO, C. et al. Estimation of coancestry in Iberian pigs using molecular markers. Conservation Genetetics, v.3, p.309-320, 2002. 